\title{
ANATOMICAL PROPERTIES AND FIBER QUALITY OF FIVE POTENTIAL COMMERCIAL WOOD SPECIES FROM CIANJUR, WEST JAVA
}

\author{
Ratih Damayanti ${ }^{1,2}$ and Sri Rulliaty ${ }^{1}$
}

\begin{abstract}
A detailed description of wood anatomy is essential for assessing the use of a wood species for processing, and also beneficial for the identification of wood samples. Computerized keys are available that allow the identification of wood samples until the genus level; however, it is not easy to use these keys to identify unknown species. Therefore, a database of anatomical characteristics and the computerized keys need to be completed up to species level. As the relevance, this study has examined the wood anatomical properties of the five corresponding tree species originated from Cianjur, West Java, which are commercially potential for their exploitation, i.e Castanopsis acuminatissima ADC. (Fagaceae); Castanopsis tungurrut ADC. (Fagaceae); Cinnamomum inners Reinw. ex Blume (Lauraceae); Ficus nervosa Heyne (Moraceae) and Horsfieldia glabra Warb. (Myristicaceae). Expectedly the results would be beneficial for wood identification purposes and evaluation for other possible uses. Observations on anatomical structures covered macroscopic and microscopic characteristics were carried out through the sectioned and macerated wood samples. The observed characteristics of the anatomical features were defined conforming to the IAWA List of Microscopic Features for Hardwood Identification. Based on the scrutiny on those observed characteristics and linked to the fiber quality, it was judged that the fiber in all the five wood species could be classified as class I for pulp and paper processing.
\end{abstract}

Keywords: Wood anatomy, fiber quality, local potential commercial species, Cianjur (West Java)

\section{INTRODUCTION}

Appropriate processing of wood, especially in drying, depends upon correct species identification, because different species and species groups require different treatments. When problems occur during wood processing (in drying, machining, or finishing), one of the first questions arises as to whether the wood was correctly identified or not (Wheeler and Bass, 1998). This problem can be minimized by applying wood identification procedure at the earliest stage of wood processing. Moreover, if procedures for identifying wood material are based on an understanding of the anatomical properties of wood, it becomes possible to develop wood products that exploit these characteristics.

Existing computerized key wood identification and the databases of anatomical structures, particularly in Indonesia, have enabled them to identify up to genus level.

\footnotetext{
${ }^{1}$ Centre for Forest Products Research and Development, Jl. Gunung Batu 5, Bogor 16000, Indonesia

${ }^{2}$ Corresponding author. E-mail: Ratih-Damayanti@forda-mof.org
} 
Specific identification up to species level usually can be done in commercial timber; however it must be assisted by 'traditional' methods. Variations in species within genus are very possible and this fact makes it difficult to recognize (Wheeler and Bass, 1998) and utilize unknown species.

There is a great potential for unknown or lesser known wood species in Indonesia to be exploited into a local commercial timber. Currently, there are about 4000 wood species available in this country (Mandang and Pandit, 2002; Pandit and Kurniawan, 2008). According to Mandang and Pandit (2002), only 400 species have been exploited for trade and have a specific trade name. Other species commonly have been known in trading as 'borneo', which is a group of mix or of any kind timber. This fact shows a limited knowledge of wood as raw material for further wood processing (Krisdianto, 2005; Pandit and Kurniawan, 2008). For these reasons it is important to complete the database of anatomical characteristics and already-computerized key wood identification to species level. This paper studied the anatomical properties of five local potential commercialized woods obtained from trees grown in Cianjur, West Java. The study will be important for species identification and assessment for possible utilization of those timbers for pulp, paper, and other processed products.

\section{MATERIALS AND METHODS}

Five local wood species regarded as potentially commercial were collected from Sukanegara Selatan, Cianjur, West Java. For scientific botanical authenticity, the herbarium specimens were identified in Herbarium Bogoriense. Profiles of these five timber species in accordance with local name, scientific name, collection number in Xylarium Bogoriense 1915, and durability class as well as strength class based on Oey (1964) are elaborated in Table 1.

Table 1. Description of collection number, name, durability class, and strength class of five local potential woods from Cianjur, West Java

\begin{tabular}{|c|c|c|c|c|c|}
\hline $\begin{array}{l}\text { Collection } \\
\text { Number }\end{array}$ & Local name & Scientific name & Family & $\begin{array}{l}\text { Durability } \\
\text { class* }\end{array}$ & $\begin{array}{l}\text { Strength } \\
\text { class }^{*}\end{array}$ \\
\hline 34331 & Ki Hiur & $\begin{array}{l}\text { Castanopsis acuminatissima } \\
\text { A. DC. }\end{array}$ & Fagaceae & III & II \\
\hline 34332 & Tunggereuk & Castanopsis tungurrut A. DC. & Fagaceae & III-II & II-I \\
\hline 34333 & Huru pedes & $\begin{array}{l}\text { Cinnamomum inners Reinw. ex } \\
\text { Blume }\end{array}$ & Lauraceae & $\mathrm{IV} / \mathrm{V}$ & $\mathrm{III} / \mathrm{II}$ \\
\hline 34335 & $\begin{array}{l}\text { Ki kanteh/ } \\
\text { Ki Julang }\end{array}$ & Ficus nervosa Heyne & Moraceae & $\mathrm{V}$ & IV \\
\hline 34336 & $\begin{array}{l}\text { Kelapa } \\
\text { ciung/ki } \\
\text { bonin }\end{array}$ & Horsfielda glabra Warb. & Myristicaceae & $\mathrm{V}$ & III/II \\
\hline
\end{tabular}

*Source: Oey (1964) 
Wood samples in the disc form of $10 \mathrm{~cm}$ in thickness were taken from three particular tree heights, i.e. bottom, middle and top portions of the corresponding logs. At each height, samples for fiber maceration were prepared from five parts moving inward radially between the pith and the bark. The location of sectioning the wood sample in heartwood area for microtome slide is marked by $V$ sign, as shown in Figure 1.

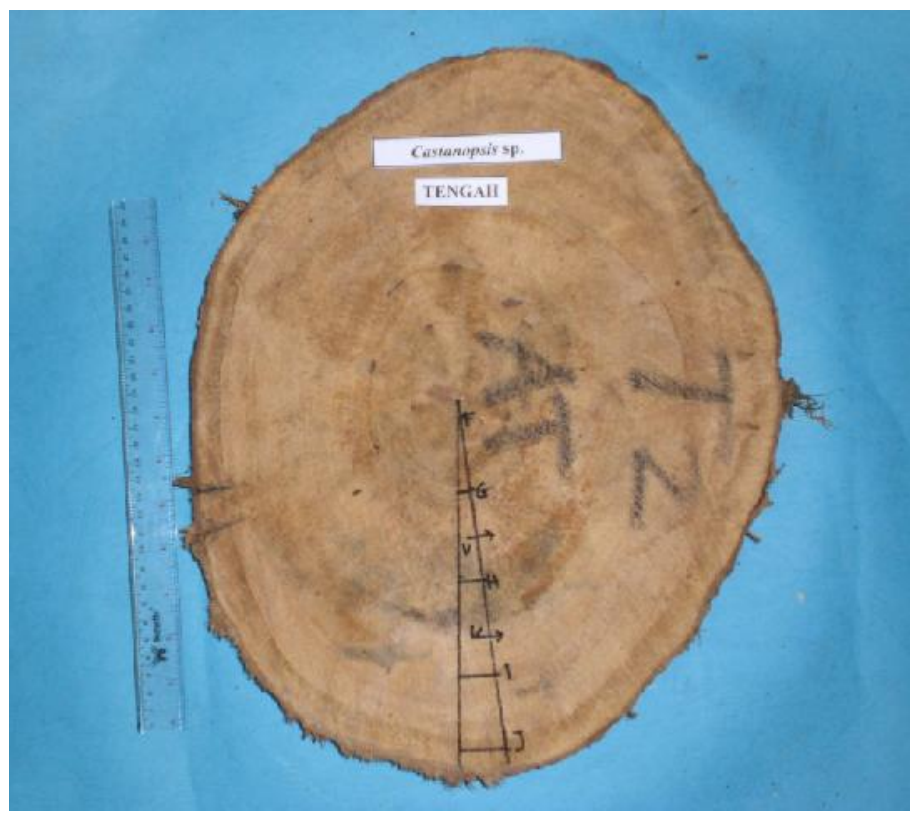

Figure 1. Cross-sectional view of the sample-cutting pattern for macerated and sectioned sample. F-J lines are the points for macerated samples, while $V$ mark reveals the location in heartwood for sectioned samples.

Observation on anatomical structures covered macroscopic (general) and microscopic characters. Macroscopic features as observed on the finished surface of the sample were suggested by Mandang and Pandit (2002) that cover color, figure, texture, slope of grain, hardness, luster, odor and surface impression.

Microscopic characteristics were examined in the sectioned samples. Three block sections prepared from heartwood were assigned for examination of anatomical features and properties on consecutively cross-sectional (transverse), radial, and tangential surfaces of the block. The block sections for such anatomical feature examination were first air-dried and then soaked in distilled water for about 1 week. After being saturated, the samples were then transferred into a container containing a softening solution of ethanol-glycerin 1:1 and further kept for about 1 week before being sectioned into 15$25 \mu$ thin slices. The good slices were chosen and washed in stages using ethanol with 
concentrations consecutively of 30,50,70, and 96\%, and ultimately absolute ethanol. The slices were cleaned to drive away the alcohol by soaking them in carboxylol and toluene. The last step in sample preparation was to mount the slices on the object glass using entellan (Damayanti et al., 2007).

The characteristics as observed with respect to the anatomical features were based on the IAWA Committee List of Microscopic Features for Hardwood Identification (Wheeler et al., 1989). Some features represented quantitative data. The quantitative data in this study signified the first measurement to be performed on certain features like tangential diameter of vessels (25-times measurements), frequency of vessels per $\mathrm{mm}$ square, frequency of rays per $\mathrm{mm}$ (10-times over ten different areas), and heights of rays (25 times), and then calculating the average (Krisdianto and Damayanti, 2007).

The quantitative data of fiber dimension (diameter and thickness of cell walls were measured 15-times, respectively) and vessel length (25-times measurements) were measured from the macerated samples. In this regard, the wood samples were macerated according to the method of Tesoro (1989). The sample materials were heated slowly at $40-60{ }^{\circ} \mathrm{C}$ in the mixture of concentrated nitric acid and hydrogen peroxide $\left(\mathrm{H}_{2} \mathrm{O}_{2}\right)$ at a ratio of $1: 1$. The heating process took about 12 hours to produce adequately macerated material or a satisfactory separation of cells for further dimensional measurement.

The separated fiber cells were washed by water to rid the cells completely free of residual acid and $\mathrm{H}_{2} \mathrm{O}_{2}$, and then the cells were dyed by safranin. To examine their dimensions, the cells were placed on the object glass; ethanol-glycerin was then added, and the cells were evenly spread on the glass using a coarse needle before closing the object glass with cover glass. The qualification of fiber for pulp and paper was based on the criteria of Nurachman and Siagian (1976), through the determination of fiber dimension and its derived values.

\section{RESULTS AND DISCUSSION}

\section{A. Anatomical Properties}

\section{Castanopsis acuminatissima A.DC. (Ki Hiur)}

General characteristics: Heartwood is generally brownish-yellow, rather easily demarcated from pale yellow sapwood. Figure is plain up to alternate lines in brown color. Texture is coarse and uneven. Grain is straight to interlocked. The wood is hard and no special odor. The longitudinal surface is slippery and lustrous.

Anatomical properties: Growth ring is indistinct. Vessels: diffuse, mostly solitary, in diagonal or dendritic pattern. Average tangential diameter is $300 \mu \mathrm{m}, 800 \mu \mathrm{m}$ in length and the frequency is $3 \mathrm{~mm}^{-2}$. Perforations plate simple. Intervessel pits alternate. Vesselray pits with much reduced borders to apparently simple, pits horizontal (scalariform, gash-like) to vertical (palisade). There are tyloses common in vessels. Vascular/vasicentric tracheids present. Axial parenchyma: axial parenchyma in narrow bands or lines up 
to three cells wide, and or scalariform axial parenchyma; 5-8 cells per parenchyma strand. Rays: homocelluler, all ray cells procumbent. This species has two distinct sizes of rays. The narrow rays are exclusively uniseriate, 8 rays per milimeter; the larger rays are commonly more than 10 seriate. Fiber: $1,750 \mu \mathrm{m}$ long; non septate; thin to thickwalled; with simple to minutely bordered pits. Mineral inclusions: prismatic crystal present in radial alligment in procumbent ray cells and chambered axial parenchyma cells. Anatomical structure of Castanopsis acuminatissima is presented in Figure 2.

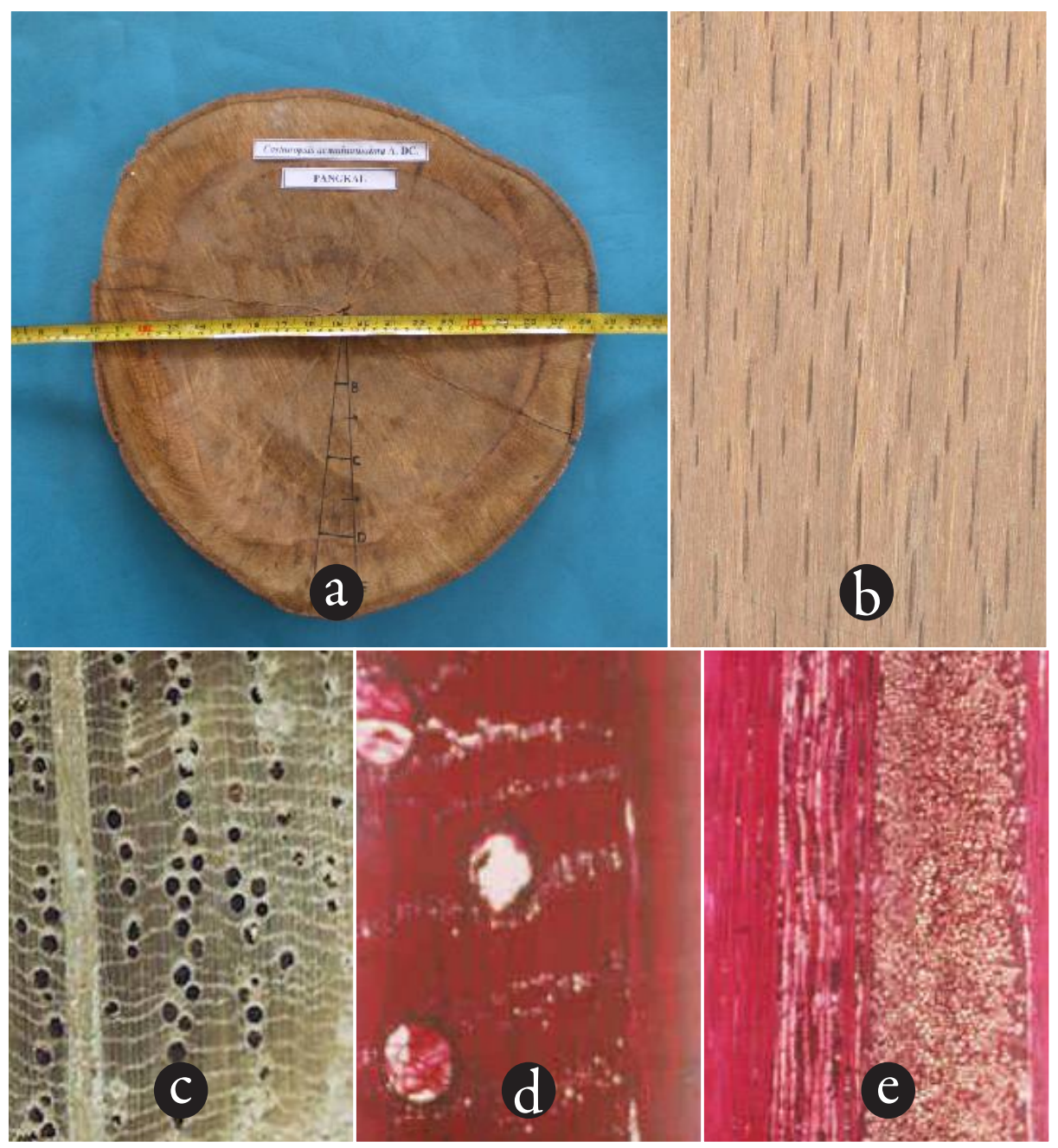

Figure 2. Castanopsis acuminatissima - Fagaceae. (a) cross sectional surface of the stem (b) longitudinal surface, $x 1$ (c) transverse surface (macroscopic), $x 10$ (d) transverse surface (microscopic), $\mathrm{x} 40$ (e) multiseriate rays $>10$ seriate and uniseriate rays, $\mathrm{x}$ 40. 


\section{Castanopsis tungurrut A.DC. (Tunggereuk) - Fagaceae}

General characteristics: Heartwood is pale brownish-yellow, indistinctly demarcated from yellowish sapwood. Figure is plain. Texture is fine and moderately even. Grain is straight to moderately interlocked. Wood is hard, slippery and not lustrous. No special odor.

Anatomical properties: Growth ring is indistinct. Vessels: diffuse, mostly soliter in radial or diagonal pattern. Average tangential diameter is $330 \mu \mathrm{m}$, length $700 \mu \mathrm{m}$, frequency $2 \mathrm{~mm}^{-2}$. Perforations plate simple. Intervessel pits alternate. Vessel-ray pits with much reduced borders to apparently simple, pits horizontal (scalariform, gash-like) to vertical (palisade). Tyloses are common in vessels. Vascular/vasicentric tracheids present. Axial parenchyma: paratracheal, banded parenchyma in narrow bands or lines up to three cells wide; 3-8 cells per parenchyma strand. Rays: exclusively uniseriate, sometimes biseriate. Homoseluler, all ray cells procumbent. Frequency 9 rays per mm. Fiber: 1,650 $\mu \mathrm{m}$ long, non-septate; thin-to thick-walled; with simple to minutely bordered pits. Mineral inclusions: prismatic crystals present in chambered axial parenchyma cells. Anatomical structure of Castanopsis tungurrut is presented in Figure 3. 

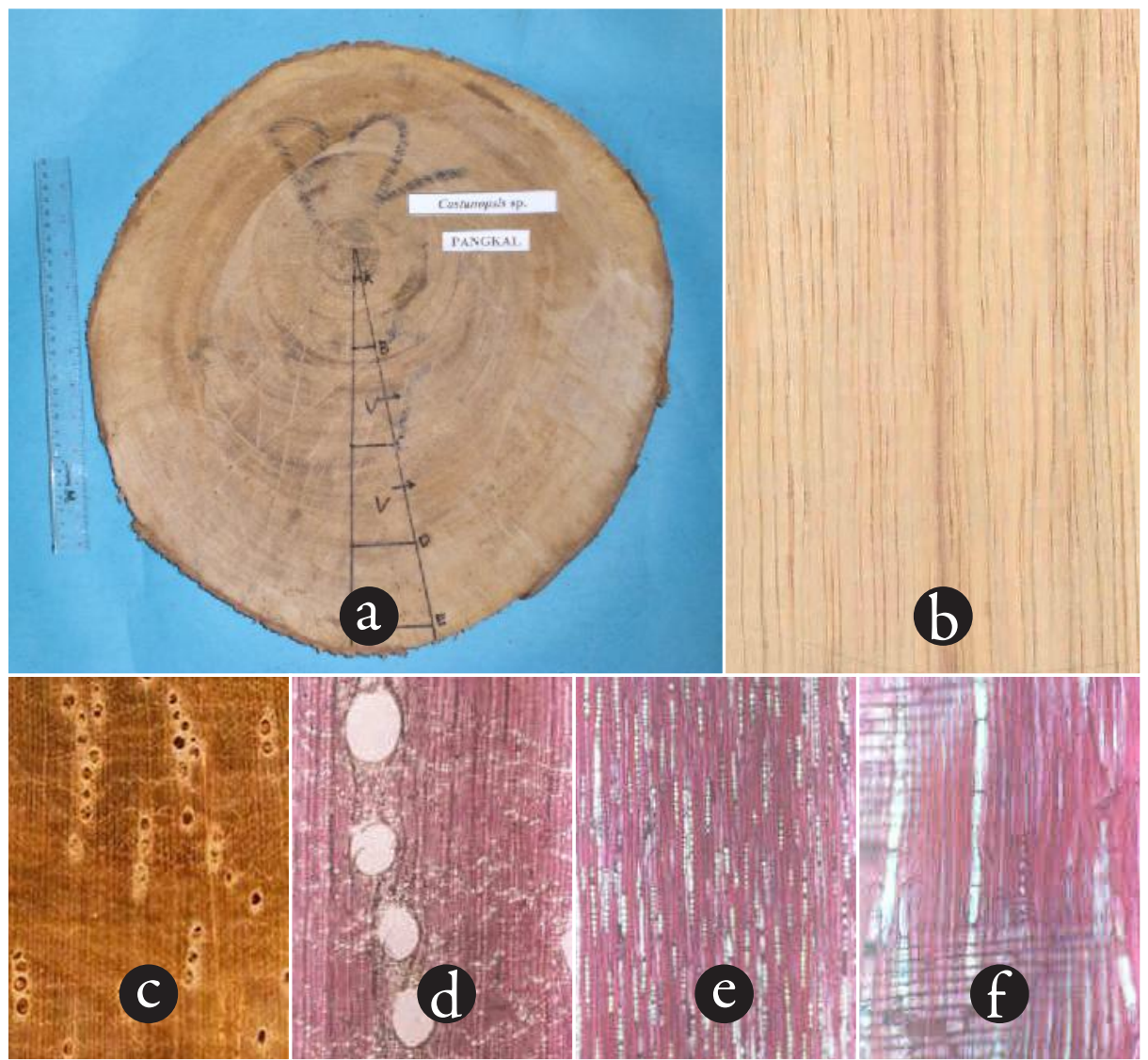

Figure 3. Castanopsis tunggurut - Fagaceae. (a) cross sectional surface of the stem, (b) longitudinal surface, $x 1$ (c) transverse surface (macroscopic), x 10 (d) transverse surface (microscopic), x 40 (e) tangential surface, uniseriate rays, $\mathrm{x} 40$ (f) prismatic chrystal in chambered axial parenchyma, $\mathrm{x} 100$.

\section{Cinnamomum inners Reinw. ex Blume (Huru Pedes) - Lauraceae}

General characteristics: Heartwood is yellowish light brown, distinctly demarcated from sapwood. Figure is plain; fine and even texture; and straight to interlocked grain. Wood is hard and has special camphor-like odor. The longitudinal surface is slippery and not lustrous.

Anatomical properties: growth ring is distinct and marked by thick-walled and flattened latewood fibers. Vessels: diffuse, average tangential diameter is $160 \mu \mathrm{m}$, length $630 \mu \mathrm{m}$ and frequency $15 \mathrm{~mm}^{-2}$. The perforations plate is simple and scalariform. Intervessel pits alternate. Vessel-ray pits have much reduced borders and apparently 
simple, pits are rounded or angular, horizontal (scalariform, gash-like) to vertical (palisade). Tyloses are commonly present in vessels. Axial parenchyma: apotracheal diffuse, paratracheal vasicentric and aliform; 3-8 cells per parenchyma strand. Rays: multiseriate, 1-3 cells width. Cellular compositions is the procumbent body ray cells with one row to $2-4$ rows of upright and/or square marginal cells. Frequency 5 rays per mm. Fiber: $1450 \mu \mathrm{m}$ long; non septate; thin-to thick-walled; with simple to minutely bordered pits. Mineral inclusions: absent. Secretory element: oil cells assosciated with ray and axial parenchyma. Anatomical structure of Cinnamomum inners is presented in Figure 4.

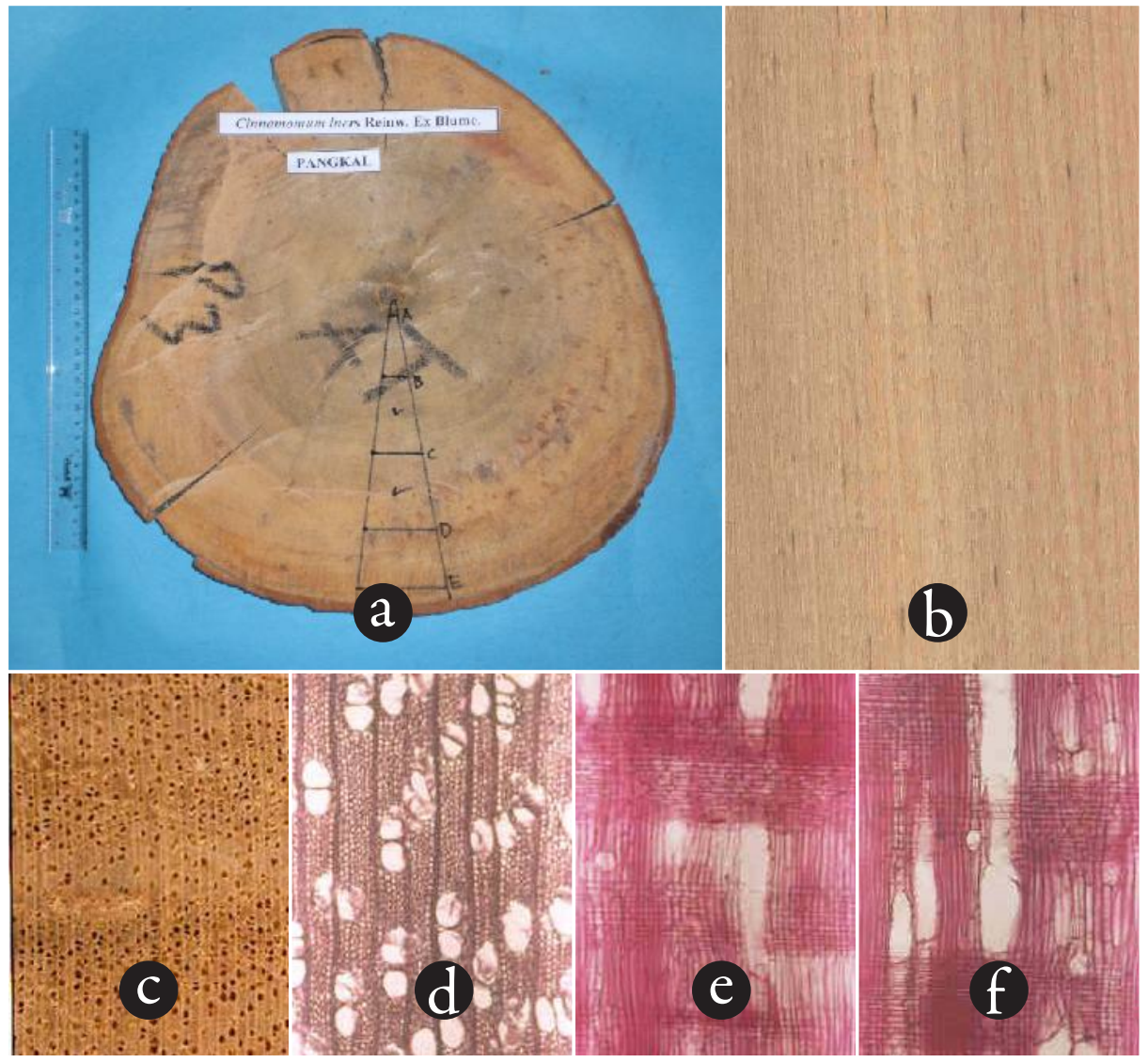

Figure 4. Cinnamomum inners - Lauraceae. (a) cross sectional surface of the stem (b) longitudinal surface, $x 1$ (c) transverse surface (macroscopic), x 10 (d) transverse surface (microscopic), x 40 (e) radial surface, $\mathrm{x} 40$ (e) oil cells assosciated with axial parenchyma, x 100 . 


\section{Ficus nervosa Heyne (Ki Kanteh/Ki Julang) - Moraceae}

General characteristics: Heartwood is yellowish white, not clearly differentiated from the sapwood. Figure is plain, sometimes there are darker colored streaks produced by parenchyma, giving rise to watered-silk figure on tangential surface, and palisade effects on radial surface. Texture is coarse and uneven due to the abundant of parenchyma. Grain is straight to deeply interlocked. Wood is soft, lusterless and rough. No special odor.

Anatomical properties: Growth ring is indistinct. Vessels: diffuse. Average tangential diameter is $230 \mu \mathrm{m}$, length $440 \mu \mathrm{m}$, frequency is $3 \mathrm{~mm}^{-2}$. Perforations plate is simple. Intervessel pits alternate, polygonal in shape. Vessel-ray pits with distinct borders, similar to intervessel pits in size and shape throughout the ray cells; vessel-ray pits with much reduced borders to apparently simple, pits rounded or angular; and vessel-ray pits unilaterally compound and coarse. Axial parenchyma: scanty paratracheal to vasicentric, apotracheal bands more than three cells wide. Rays: multiseriate, 1-10 seriate. Frequency is 6 rays per mm. Cellular compositions are the procumbent body ray cells with one row, $2-4$ rows, and up to more than 4 rows of upright and/or square marginal cells. Fiber: $1600 \mu \mathrm{m}$; non septate; very thin, thin-to thick-walled; with simple to minutely bordered pits. Mineral inclusions: absent. Another feature: axial parenchyma and fibers storied. Anatomical structure of Ficus nervosa is presented in Figure 5. 


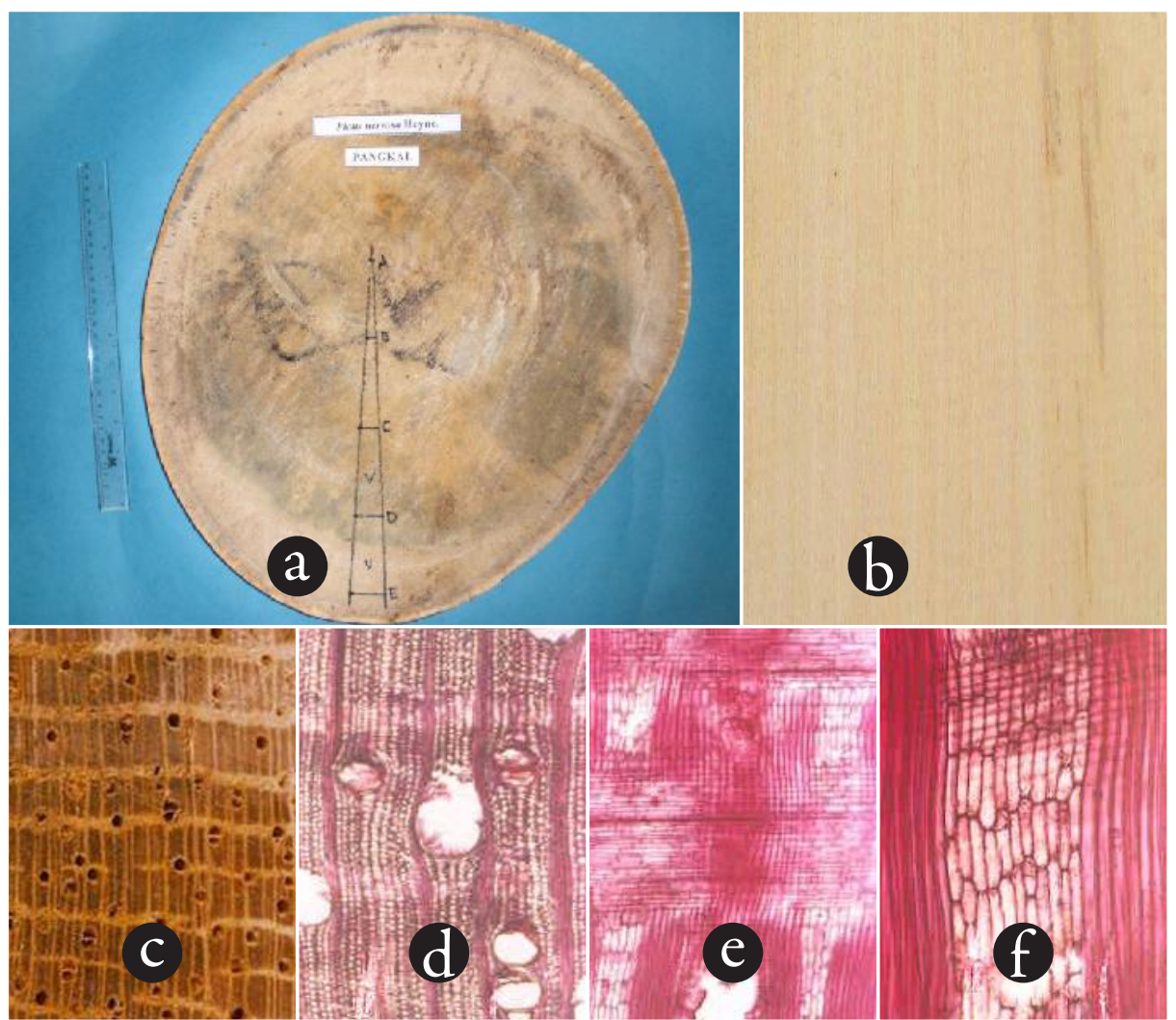

Figure 5. Ficus nervosa - Moraceae (a) cross sectional surface of the stem (b) Longitudinal surface, x 1 (c) transverse surface (macroscopic), x 10 (d) transverse surface (microscopic), x 40 (e) radial surface, x 40 (f) axial parenchyma storied, x 100.

\section{Horsfielda glabra Warb. (Kelapa ciung/ki bonin) - Myristicaceae}

General characteristics: Heartwood is reddish light brown, difficult demarcated from the pale brownish yellow sapwood. Figure is plain. Texture is fine and even. Grain is straight to interlocked, sometimes slighty wavy. Wood is moderately hard, rather rough, and lusterless. No special odor.

Anatomical properties: Growth ring is indistinct. Vessels: diffuse. Average tangential diameter is $170 \mu \mathrm{m}, 1100 \mu \mathrm{m}$ length, frequency $7 \mathrm{~mm}^{-2}$. Perforations plate is simple. Intervessel pits opposite to alternate. Vessel-ray pits is very complex, there are four types of vessel-ray pits, being first, with distinct borders, similar to intervessel pits in size and shape throughout the ray cells; second and third, vessel-ray pits with much reduced borders to apparently simple, pits rounded or angular; pits horizontal (scalariform, gash-like) to vertical (palisade); and fourth, vessel-ray pits of two distinct sizes or types 
in the same ray cells. Tyloses common are present in vessels. Axial parenchyma: scanty paratracheal to vasicentric; banded parenchyma in narrow bands or lines up to three cells wide; axial parenchyma in marginal or in seemingly marginal bands; $5-8$ cells per parenchyma strand. Rays: multiseriate, 1-10 seriate cells width. Cellular compositions is the procumbent body ray cells with one row to $2-4$ rows of upright and/or square marginal cells; and rays with procumbent, square and upright cells mixed throughout the ray. Frequency 7 rays per mm. Fiber: $1400 \mu \mathrm{m}$ long, non septate; thin-to thick-walled; with simple to minutely bordered pits. Mineral inclusions: druses present in chambered cells. Anatomical structure of Horsfieldia glabra is presented in Figure 6.

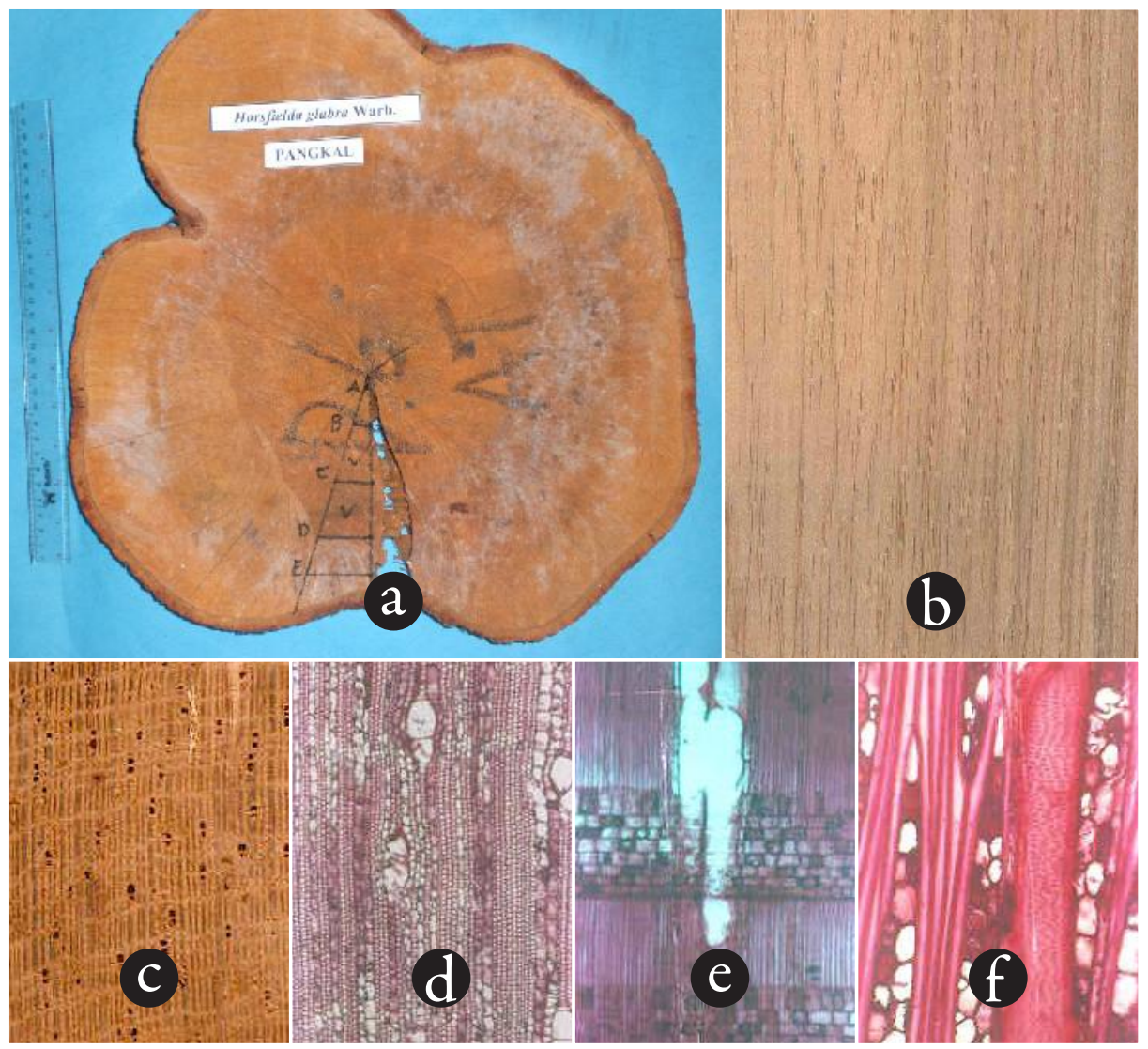

Figure 6. Horsfielda glabra - Myristicaceae. (a) cross sectional surface of the stem (b) longitudinal surface, $\mathrm{x} 1$ (c) transverse surface (macroscopis), x 10 (d) transverse surface (microscopic), x 40 (e) radial surface, $x 100$ (f) the alternate and opposite intervessel pits, $\mathrm{x} 100$. 
Microscopically, woods from the families Fagaceae (Castanopsis sp.), Moraceae (Ficus sp.) and Myristicaceae (Horsfieldia sp.) have indistinct growth rings, in contrast to the Lauraceae family (Cinnamomum sp.) which has distinct growth rings because of its thick-walled and flattened latewood fibers.

Belonging to the same genus and family, Castanopsis acuminatissima (Ki Hiur) and C. tungurrut (Tunggereuk) have the same porosity, vessel arrangement, fibers and axial parenchyma structures. However, Ki Hiur tends to have an axial parenchyma scalariform pattern. Further, the structure in rays is very different. While both species have uniseriate ray width, exclusively uniseriate in $C$. tungurrut, but $C$. acuminatissima also has very wide multiseriate rays (more than 10 seriate) that give this species two distinct sizes of rays. Another difference is that mineral inclusion in C. acuminatissima is more abundant than that in $C$. tungurrut. In $C$. tungurrut, crystal can be observed both in procumbent ray cells and chambered axial parenchyma cells, whereas in C. acuminatissima, crystal can only be observed in chambered axial parenchyma.

Aside from the presence of distinct growth ring boundaries, features of the Lauraceae family $(C$. inners), that differ from other families include the presence of scalarifom perforation plates in the vessel and the existence of oil/mucilage cells associated with ray and axial parenchyma. These cells function to exude the aromatic fragrance that makes this species special.

Ficus nervosa (Moraceae family) has specific characteristics that include regular axial parenchyma bands more than three cells wide and very complex vessel-ray pitting. Three features can be observed comprising vessel ray-pits with distinct borders similar to intervessel pits in size and shape throughout the ray cells; vessel-ray pits with much reduced borders to apparently simple, pits rounded or angular; and vessel-ray pits unilaterally compound and coarse.

The specific characteristics of Horsfieldia glabra are the opposite and alternate intervessel pits present in the vessel cell. Vessel-ray pitting is multivarious and four features can be observed being vessel ray-pits with distinct borders-similar to intervessel pits in size and shape throughout the ray cells; vessel-ray pits with much reduced borders to apparently simple; pits horizontal (scalariform, gash-like) to vertical (palisade); and vessel-ray pits of two distinct sizes or types in the same ray cells. This species has many variaties of heterocellular rays with the procumbent body of ray cells boundaried with one row; $2-4$ rows, and over 4 rows of upright and/or square marginal cells; and rays with procumbent, square and upright cells mixed throughout the ray.

For wood identification purposes, the diagnostic characteristics from these timbers are:

1. Castanopsis acuminatissima: heartwood brownish yellow, sapwood pale yellow. Figure alternate lines in brown color. Vessels exclusively solitary and in diagonal or radial pattern. Vascular/vasicentric tracheids present. Rays of two distinct sizes, narrow 
(uniseriate) and wide (multiseriate). Prismatic crystals present in radial alignment in procumbent ray cells and in chambered axial parenchyma cells.

2. Castanopsis tungurrut: heartwood pale yellow, brownish, hardly demarcated from yellowish sapwood. Vessels exclusively solitary and in diagonal or radial pattern. Vascular/vasicentric tracheids present. Only one size of rays (uniseriate), homocelular, just comprising of procumbent cells. Prismatic crystals present in chambered axial parenchyma cells.

The differences between $C$. acuminatissima and C. tungurrut are the two distinct sizes of rays in C.acuminatissima; the homocelular composition that is procumbent in $C$. tungurrut; and the prismatic crystal present in both radial alignment in procumbent ray cells and in chambered axial parenchyma cells in $C$. tungurrut which can only be observed in chambered axial parenchyma cells in C. acuminatissima.

3. Cinnamomum inners: heartwood pale brown, yellowish, clearly differentiated from the sapwood. The wood has a persistent camphor-like odor. Growth ring boundaries distinct. Perforation plate simple and scalariform. Oil cells associated with ray and axial parenchyma.

4. Ficus nervosa: the color of wood is yellowish white. Three characteristics of vessel ray pits (vessel-ray pits with distinct borders, similar to intervessel pits in size and shape throughout the ray cells; with much reduced borders to apparently simple, pits rounded or angular; and vessel-ray pits unilaterally compound and coarse). Axial parenchyma bands more than three cells wide in regular pattern. Axial parenchyma and fibers storied.

5. Horsfieldia glabra: heartwood pale brown, reddish, not clearly demarcated from the pale brownish yellow sapwood. Intervessel pits opposite and alternate. Four characteristics of vessel ray pits (vessel-ray pits with distinct borders, similar to intervessel pits in size and shape throughout the ray cells; with much reduced borders to apparently simple, pits rounded or angular, and pits horizontal (scalariform, gashlike) to vertical (palisade); and vessel-ray pits of two distinc sizes or types in the same ray cells). Mineral inclusions, druse, present in chambered cells.

\section{B. Fiber Quality}

Measurements and calculations of wood fiber dimensions are presented in Table 2. 
Table 2. Average value of fiber wood dimension

\begin{tabular}{lcccc}
\hline \multirow{2}{*}{ Timber Species } & \multicolumn{4}{c}{ Fiber dimensions $\left.(\mu \mathrm{m})^{\circ}\right)$} \\
\cline { 2 - 5 } & $\begin{array}{c}\text { Length } \\
(\mathrm{L})\end{array}$ & $\begin{array}{c}\text { Diameter } \\
(\mathrm{d})\end{array}$ & $\begin{array}{c}\text { Lumen } \\
(\mathrm{e})\end{array}$ & $\begin{array}{c}\text { Wall thickness } \\
(\mathrm{w})\end{array}$ \\
\hline Castanopsis acuminatissima & $1,768.1 \pm 150.5$ & $30.1 \pm 4.2$ & $26.0 \pm 4.1$ & $2,0 \pm 0,4$ \\
Castanopsis tungurrut & $1,676.3 \pm 133.0$ & $32.7 \pm 3.1$ & $28.3 \pm 3.1$ & $2,2 \pm 0,4$ \\
Cinnamomum inners & $1,460.3 \pm 221.6$ & $38.3 \pm 3.3$ & $33.2 \pm 3.2$ & $2,5 \pm 0,4$ \\
Ficus nervosa & $1,419.4 \pm 140.5$ & $40.6 \pm 4.7$ & $35.7 \pm 4.6$ & $2,5 \pm 0,5$ \\
Horsfielda glabra & $1,662.2 \pm 154.0$ & $35.8 \pm 4.1$ & $30.9 \pm 3.7$ & $2,4 \pm 0,5$ \\
\hline
\end{tabular}

') Average of 375 fibers measurement

Calculation of fiber dimension derived value and determination of class quality for pulp and paper were based on the procedure and criteria of Nurachman and Siagian (1976) presented in Table 3.

Table 3. Fiber dimension derived value and fiber class quality for pulp and paper

\begin{tabular}{|c|c|c|c|c|c|c|c|c|}
\hline \multirow[b]{2}{*}{$\begin{array}{c}\text { Wood Species/ } \\
\text { Grade }\end{array}$} & \multirow{2}{*}{$\begin{array}{c}\text { Fiber } \\
\text { length } \\
(\mu \mathrm{m})\end{array}$} & \multicolumn{7}{|c|}{ Derived values of fiber dimension } \\
\hline & & $\begin{array}{c}\text { Runkel } \\
\text { ratio }\end{array}$ & $\begin{array}{l}\text { Felting } \\
\text { power }\end{array}$ & $\begin{array}{l}\text { Flexibility } \\
\text { ratio }\end{array}$ & $\begin{array}{l}\text { Coefficient } \\
\text { of rigidity }\end{array}$ & $\begin{array}{l}\text { Muhlsteph } \\
\text { ratio }\end{array}$ & $\begin{array}{l}\text { Score } \\
\text { total }\end{array}$ & $\begin{array}{l}\text { Quality } \\
\text { Class }\end{array}$ \\
\hline $\begin{array}{l}\text { Castanopsis } \\
\text { acuminatissima }\end{array}$ & $1,768.1$ & 0.15 & 58.74 & 0.86 & 0.07 & 25.39 & 500 & I \\
\hline Grade & 50 & 100 & 50 & 100 & 100 & 100 & & \\
\hline $\begin{array}{l}\text { Castanopsis } \\
\text { tungurrut }\end{array}$ & $1,676.3$ & 0.16 & 51.26 & 0.87 & 0.07 & 25.10 & 500 & I \\
\hline Grade & 50 & 100 & 50 & 100 & 100 & 100 & & \\
\hline $\begin{array}{l}\text { Cinnamomum } \\
\text { iners }\end{array}$ & $1,460.3$ & 0.15 & 38.13 & 0.87 & 0.07 & 24.86 & 475 & I \\
\hline Grade & 50 & 100 & 25 & 100 & 100 & 100 & & \\
\hline Ficus nervosa & $1,419.4$ & 0.14 & 34.96 & 0.88 & 0.06 & 22.68 & 175 & $\mathbf{I}$ \\
\hline Grade & 50 & 100 & 25 & 100 & 100 & 100 & 475 & 1 \\
\hline $\begin{array}{l}\text { Horsfielda } \\
\text { glabra }\end{array}$ & $1,662.2$ & 0.16 & 46.43 & 0.86 & 0.07 & 25.98 & 475 & I \\
\hline Grade & 50 & 100 & 25 & 100 & 100 & 100 & & \\
\hline
\end{tabular}

Remarks:
1) Runkel Ratio

$$
=2 \mathrm{w} / 1
$$$$
\mathrm{L}=\text { Fiber length }
$$
2) Felting power
$=\mathrm{L} / \mathrm{d}$
$\mathrm{d}=$ Fiber diameter
3) Flexibilty ratio
$=1 / \mathrm{d}$
$\mathrm{l}=$ Lumen diameter
4) Coefficient of rigidity $=w / d$
$\mathrm{w}=$ Wall thickness
5) Muhlstep ratio
$=\frac{\left(d^{2}-1^{2} \times 100 \%\right)}{d^{2}}$
(Source: Nurachman and Siagian, 1976) 
Based on the calculation results in Table 4, the fiber quality of the five wood species as proposed materials for pulp and paper can be judged as class I. According to Nurachman and Siagian (1976), the wood characteristics of class I fiber quality cover moderate to low density wood species (strength class IV/V) with extremely thin wall and wide lumen. Fibers collapse completely during pulp sheet forming; flattenning and felting characteristics are high, resulting in high tear, burst and tensile strength of the corresponding pulp.

Usually, wood species with fiber quality of class I belong to strength class IV/V. Based on Oey (1964), the strength classes of Castanopsis spp. fall into II-I, while those of Cinnamomum inners and Horsfieldia glabra are III-II, which does not match that as proposed by Nurachman and Siagian (1976). The possible explanation is that there are considerable decreases in density and strength class for the woods that have been examined by Oey (1964) compared to the woods of the similar kinds this time. As this was still a preliminary study, further investigation is required to clarify this uncertainty. Moreover, to obtain more reliable results to support basic classification in determining the quality of pulp and paper processing, future research should also examine the chemical components of the wood such as cellulose, lignin, pentosan, extractive and ash contents.

\section{Evaluation of Possible Uses}

According to Lemmens et al. (1995), Castanopsis is suitable for medium to heavy construction under cover like for house posts, lining, bridges, furniture, flooring, plywood, sliced veneer, packing cases, pallets, fence posts, mine props, shingles, shakes, boat building and firewood. Cinnamomum inners is suitable for decorative work such as interior finish and paneling, for furniture, cabinet making, lining chests, and wardrobes; and is suitable for plywood manufacture.

For Ficus and Horsfieldia, according to Sosef et al. (1998), Ficus is appropriate for temporary construction, mouldings, interior work, cladding, drawers, concrete formwork, dugouts, laundry tubs, small domestics article, fruit crates, floats and firewood. From the same reference, Horsfieldia usually can be used for light or temporary construction, flooring, boat building, interior trim, joinery, wall paneling, shelving, lining, mouldings, sporting goods, packing cases, crates, matchboxes and match splints, and for production of particle board and plywood.

Of the five wood species examined, according to the traditional wood uses, Castanopsis spp, Ficus nervosa and Horsfieldia glabra, will be problematic in the processing because of the presence of unideal anatomical structures. The abundant presence of non structural tissue, such as ray parenchyma and axial parenchyma, may inflict significant damage and defects during wood drying. These groups of woods tend to be susceptible to splitting and cracking. They need special treatment such as sawing the wood into thin lumber. The wavy grain in Horsfieldia glabra must be considered in wood processing, 
especially in planning and sawing. However, the regular bands of parenchyma in Ficus nervosa and Horsfieldia glabra make them possible for use as pencil materials.

\section{CONCLUSION}

This study has scrutinized deeply the anatomical properties and diagnostic characteristics of five wood species originated (indigenous) from Cianjur (West Java), i.e. Castanopsis acuminatissima A.DC. (Fagaceae), Castanopsis tungurrut A.DC. (Fagaceae);,Cinnamomum iners Reinw. ex Blume (Lauraceae); Ficus nervosa Heyne (Moraceae) and Horsfieldia glabra Warb. (Myristicaceae), which are all commercially potential to be exploited.

Further, the acquired data and information regarding those anatomical properties and diagnostic feature can be expectedly beneficial to complete Xylarium Bogoriense 1915 key of wood identification. Judging from the preliminary study on fiber quality, all five wood species could be categorized as class I for pulp and paper processing. However, those five wood species have its own specific charactereristics that deserve thorough consideration for particular processing not only for pulp and paper but also for other wood products.

\section{ACKNOWLEDGEMENTS}

The authors would like to deeply appreciate Mr. Usep Sudardji and Ms. Tutiana for their meliculous helps in preparing the sectional and macerated slides, and in measuring the dimensions of wood fibers.

\section{REFERENCES}

Damayanti, R., Y.I. Mandang, and T.K. Waluyo. 2007. Struktur anatomi dan kualitas serat batang kemenyan (Styrax spp.) dari Sumatera Utara. Jurnal Penelitian Hasil Hutan 25 (3): 272-289 (in Indonesian with English abstract).

Krisdianto. 2005. Anatomi dan kualitas serat tujuh jenis kayu kurang dikenal dari Jawa Barat. Jurnal Penelitian Hasil Hutan 23 (4): 259-282 (in Indonesian with English abstract).

Krisdianto and R. Damayanti. 2007. Anatomical properties and fiber dimension of prickly acacia (Acacia nilotica L.) from Baluran National Park. Journal of Forestry Research 4 (2): 93-103.

Lemmens, R.H.M.J., I. Soerianegara and W.C. Wong. 1995. Plant Resources of South East Asia 5(2), Timber trees: Minor Commercial Timbers. PROSEA Foundation Indonesia. Bogor. 655p. 
Mandang, Y.I. and I.K.N. Pandit. 2002. Pedoman Identifikasi Jenis Kayu di Lapangan. Yayasan Prosea, Bogor dan Pusat Diklat Pegawai SDM Kehutanan, Bogor. 194p.

Nurachman, A.N. and R.M. Siagian. 1976. Dimensi Serat Jenis Kayu Indonesia. Laporan No.75. Lembaga Penelitian Hasil Hutan, Bogor. 11p.

Oey, D.S. 1964. Berat Jenis Kayu Indonesia dan Pengertian Berat Jenisnya untuk Keperluan Praktek. Pengumuman No.13, Lembaga Penelitian Hasil Hutan, Bogor. $234 \mathrm{p}$.

Pandit, I.K.N. and D. Kurniawan. 2008. Sifat Kayu sebagai Bahan Baku dan Ciri Diagnostik Kayu Perdagangan Indonesia. Centium, Bogor. 114p.

Sosef, M.S.M., L.T. Hong and S. Prawirohatmodjo. 1998. Plant Resources of South East Asia 5 (3), Timber trees: Minor Commercial Timbers. PROSEA Foundation Indonesia, Bogor. 859p.

Tesoro, F.O. 1989. Methodology for Project 8 on Corypha and Livistona. Forest Products Research and Development Institute, College, Laguna 4031. Philippines.

Wheeler, E.A. and P. Baas. 1988. Wood identification: A review. IAWA Journal 19 (3): 241-264.

Wheeler, E.A., P. Baas and E. Gasson. 1989. IAWA (International Association of Wood Anatomist) list of microscopic features for hardwood identification. IAWA Bulletin 10(3): 219-332. 